\title{
The Saudi Tatweer Education Reforms: Implications of Neoliberal Thought to Saudi Education Policy
}

\author{
Bilal M. Tayan ${ }^{1}$ \\ ${ }^{1}$ Graduate School of Education, Exeter University, United Kingdom \\ Correspondence: Bilal M. Tayan, Graduate School of Education, Exeter University, United Kingdom. E-mail: \\ bt275@exeter.ac.uk
}

Received: November 1, 2016

Accepted: December 9, $2016 \quad$ Online Published: April 29, 2017

doi:10.5539/ies.v10n5p61

URL: https://doi.org/10.5539/ies.v10n5p61

\begin{abstract}
The King Abdullah Public Education Development Project or the 'Tatweer' education reforms were created to improve the quality of teaching and learning in Saudi Arabia. It was a response to develop generations of Saudis who would contribute to the economic well-being of the nation. The Saudi Tatweer education reforms have been important in highlighting questions about power, globalisation and divergence. Therefore, set against a background of neoliberal discourse, I will assess the influences and impact of the drivers within Tatweer - a seemingly market-driven set of education reforms. With reference to Foucauldian thought on power and governance, I will also raise some questions on whether the Tatweer reforms were rigorous and effective enough in improving the level of education within the Saudi context. Finally, I will consider the importance of Ball's (2003) perspective on performativity, and how market forces and international influence have impacted on Saudi education policy reform.
\end{abstract}

Keywords: Neoliberalism, Saudi education reform, Tatweer

\section{Introduction}

In 2007, the Saudi Ministry of Education implemented an education policy aimed at improving literacy levels at state schools. The King Abdullah Public Education Development Project, or 'Tatweer', literally meaning ' to develop', was created to improve the quality of teaching and learning through (i) the employment of new teacher professional development initiatives; (ii) the implementation of new learning technologies in classrooms; and (iii) the development of greater teacher autonomy in state schools. The new standards aimed to improve the education of students and consequently develop the "overall quality of education-in turn producing generations of Saudis who would contribute to the development of the nation and society" (SUSRIS, 2015:1). However, the Tatweer reforms raise a number of questions regarding the Saudi teaching profession. As an educator working within the Saudi education context, I am interested in understanding this seemingly market-driven education policy. I will therefore critically discuss Tatweer in terms of the impact it has on my colleagues and the teaching profession in the Kingdom of Saudi Arabia (KSA) as a whole. Set against a background of neoliberal discourse, I will assess the influences of the mechanisms and subjects within Tatweer, with reference to Foucauldian thought on power and governance, to allow for a greater exploration of the potential outcomes and implications of the policy. In turn, I would be able to raise some questions as to whether the Tatweer reforms were rigorous and effective enough in improving the level of education within the Saudi context. Finally, as literature on neoliberalism is limited in scope within the Saudi context of education research (Chinnammai, 2005), I will consider the importance of Ball's (2003) perspective on performativity, a driver of the reform, and the extent to which market forces and the influence of international test scores have impacted on Saudi education policy reform.

\section{Factors That Have Shaped Tatweer}

The \$2.4 billion King Abdullah Public Education Development Project, commonly referred to as Tatweer, was implemented in 2007 to improve the educational competence of the Saudi population in order to create a productive and efficient workforce within a dynamic and innovative economy (Tatweer, 2010). The Tatweer education reforms were based on neoliberal principles and led to a new context of education delivery in Saudi Arabia (Wiseman, Astiz, \& Baker, 2013). 
In neoliberal thought, literacy is associated with a number of values, including social cohesion, social capital and political participation (Niblock, 2006). It is seen as a benchmark to a successful and an effective education system within a globally competitive dynamic knowledge-based society (Chinnammai, 2005). In attempting to promote economic prosperity and position itself in the global marketplace, Saudi Arabia sought to reform its education system to increase literacy and numeracy levels in schools to (i) create a workforce that is would be more educated and competent than previous generations; (ii) to generate economic prosperity within the nation and; (iii) to meet global labour market needs. Here, the objective of Tatweer - a seemingly market-driven, market-orientated reform - becomes clearly visible from the opening commentary on the official state website: "the primary objective of this program will be to focus on the quality of education to ensure that students of public education in the Saudi Kingdom are equipped with the necessary skills to participate in an increasingly globalised society and engage with the complex and myriad problems that globalisation brings" (Tatweer, 2010, cited in Elyas \& Picard, 2013, p. 36).

With this overt hegemonic neoliberal idea supporting this policy, an explicit relationship to Foucault's (1991) knowledge-power relationship can be presented, where quality of education over equity of education, is a driving force to economic prosperity in society. Here, quality education, developing skills and literacy levels to meet an ever increasing globalised Saudi society-a knowledge economy-has become a marketable commodity, a drive which Ball (2008) argues, is crucial to a country's position within an increasingly connected and competitive world. Understanding Tatweer's policy orientation towards developing a knowledge economy can be understood with reference to Ball's $(2008$, p. 20) definition of the term, in which the "increasing role of knowledge as a factor of production and the ability to produce and use it is seen as a major factor in economic development and critical to a nation's competitive advantage". Essentially, Ball (2008) suggests that education is viewed as a commercial marketable commodity, a knowledge-power driver emerging as a result of globalisation. Here, globalisation can be defined as an international amalgamation of economies, societies, language and culture arising from the interchange of ideas, trade, immigration and policy-making (Dicken, 2011). Yet, within the context of education reform in Saudi Arabia, Wiseman et al. (2013) argue that neoliberalism is the foundation on which authoritative control is exerted in Tatweer. Thus, the central features of Tatweer are the power control drivers associated with neoliberalism. These are noted and reaffirmed by Sahlberg (2007, p. 150), where he asserts that "the standardisation of education, where reform is based on student and school performance, increased targets for numeracy and literacy as a determinant factor to a successful education system, and the application of accountability systems where teachers and schools are given more responsibility for the performance of their teaching and schools." These drivers are not only the result of state power and authority but also the result of supranational agencies of power and influence (Lascoumes \& Le Gales, 2007). These include UNESCO, the Trends in International Mathematics and Science Study (TIMSS) administered by the International Association for the Evaluation of Educational Achievement (IEA) and the Programme of International Student Assessment (PISA) administered through the Organisation for Economic Co-operation and Development (OECD). I will later discuss that these agencies are influential in driving Tatweer through the state's capacity in applying neo-institutional frameworks to form its policy-a policy which aimed "to create a world-class and self-sustaining knowledge workforce that can compete effectively at the global level" (Wiseman et al., 2013, p. 42). This was to be achieved through teacher support, training and development initiatives to raise the literacy and numeracy levels of students and, school environment and technology reforms. I can thus argue that Tatweer purports the following: reengineering of education policy through school/technology reform and competitive economic drivers put in motion to accelerate the production of a nation under market values. Tatweer was therefore introduced as an educational policy to create a well-trained society that met the realities of the labour market and attain economic prosperity. Thus, built on the foundations of education as a market commodity, it is arguable that Tatweer was the outcome of globalisation pushed by international comparative testing and supranational agents that work predominantly through an agenda setting strategy.

Furthermore, I will later show that Tatweer created "value schizophrenia" among educators, with teachers trying to reconcile their commitment to their learners while being seen to perform (Ball, 2003, p. 221). This would create an unstable reform 'epidemic' pushed by powerful supranational agents through their policy publications, national reports and working papers (Ball, 2003; Wiseman et al., 2013). As such, Tatweer demonstrates an articulation of power and authority to create social cohesion by exerting power to influence outcomes, i.e., greater literacy. This is related to Foucault's (1991) concept of governmentality, or the structures of power by which action is governed and disciplinarily power is excercised to shape and guide individuals to a system of accountability in conduct. Consequently, I can claim that Tatweer provides a useful analysis of an agenda-driven education reform that intertwines education development with economic goals by "blending overlapping context of educational and economic development in a non-Western system" (Wiseman et al., 2013, p. 38). 
Tasked with supplying educational technology and resources in the classroom to support curriculum design, it was not until the introduction of the Tatweer initiative that a rapid development of education reform was witnessed through strongly emphasised information communication technology (ICT) based approaches to learning and teaching in Saudi state schools. The Tatweer education policy reform was established as an education reform initiative that modeled a society built on prosperity, growth and wellbeing, particularly in the field of economic self-development and reliance (Tatweer, 2010, cited in Elyas \& Picard, 2013). The Tatweer project quickly saw the creation of 50 Tatweer Smart Schools. Tatweer Smart Schools (TSSs) quickly became a product of economic and productive reform in the Saudi education sector, and would later witness the government's commitment to fund public education surpassing its $\$ 40.8$ billion budget by nearly $20 \%$ (Wiseman, Astiz, \& Baker, 2013). The Saudi Ministry of Education's rationale for significantly exceeding its education budget and implementing the Tatweer project was not only a response to the phenomena of the rapidly growing school-age population common throughout the Gulf Community Countries (GCC), but also because the demand to increase the use of ICTs to modernise curricula and improve teaching methods and learning among students was part of the country's commitment to developing its human capital and an attempt to position itself in the global knowledge-based economy. Here, Tatweer visably becomes a knowledge-based, knowledge-creating and knowledge-proliferating actor that functions as a provider and disseminator of information to legitimise power controls and government reforms-essentially becoming a driver of legitimised policy that was primarily meant to transform the country into a state that was distinct from other GCC countries. As Tatweer was formed to establish "inquiry-based 21st century education", the Tatweer Smart Schools signified the beginning of the Tatweer reforms. These schools aimed at improving teachers' professional development to increase quality education and exponentially exploit and integrate ICTs into the teaching and learning cycle to improve learner numeracy and literacy levels (Wiseman et al., 2013, p. 40). However, before exploring the reforms in greater depth, I believe that we need to understand the context in which the Tatweer reforms evolved from.

\subsection{The Evolution of Tatweer}

Tatweer emerged from a number of events. The growing crisis in the Saudi education system with in its inability to develop a dynamic knowledge society that accelerated economic development, the aftermath of 9/11, WTO membership and labour market needs were all drivers that highlighted the need for reform. Therefore, to understand the development of Tatweer, I believe considering the role of the regional context, WTO membership and the TIMSS \& PISA measurements are essential.

\subsubsection{The Regional Context}

Throughout the late 20th century, debates in the Middle East and North African countries (MENA) highlighted the crisis of the Arab education system, at a time which witnessed an exponential growth in the population and early signs of increasing unemployment. During this period, UNESCO estimated that "more than 90 percent of the Saudi Arabian population was illiterate" (Wiseman, Sadaawi, \& Alromi, 2008, p. 3). Consensus grew that recognised the fundamental need to restructure the education systems in the MENA countries in order to assist in effectively educating an undertrained workforce who would fill labour market jobs, especially in the growing Saudi oil industry (IMF, 2013; World Bank, 2008). While constructs of teaching in Saudi Arabia revolved around the conservative principles of Islamic philosophical thought, or Wahabbism, it was the catastrophic events of 9/11 that pushed neoliberal Western ideologies into the forefront of Saudi education policy reform (Elyas, 2013). The impact of the multiple attacks on symbolic locations in the United States was felt as a social catastrophe that rocked the entire globe. The scale and magnitude of the attacks on Western soil created anger and animosity towards Saudi Arabia, particularly because 15 of the 19 terrorists were Saudi nationals. Consequently, the Saudi Arabian system of education was quickly criticised as an establishment that worked to isolate, and not recognise or appreciate Western values, freedoms and norms (Prokop, 2003). Elyas (2013) argues that a vacuum was created with power struggles between the Saudi and American governments become intense, with Washington accusing Riyadh, in part, of creating the circumstances for extremism to grow. For Niblock (2006, pp. 173-177), by late 2005, the Saudi labour market was still "ill-suited to a competitive environment". However, published literature, working papers and consultations from the United Nations Development Fund (2003) and the World Bank (2008) were working to set the agenda for much reform in the Middle East. Carefully steering Saudi education policy, the realisation of reconstructing a modern and revolutionary education system that would employ hegemonic liberal values, including human capital growth, in terms of skills and knowledge development for economic goals, were pivotal in reform (Al-Essa, 2009). Here, the significance of knowledge creation, knowledge sharing and skills development began to present itself as fundamental to any type of development in the Saudi Arabian education system. Creating the circumstances in which human capital is managed and developed in such a way that works to stimulate financial growth and create social cohesion, is 
recognised by Ball as (2008:20) "critical to a nation's competitive advantage". Within the Saudi context, reform began on the principles of addressing underachieving students who lacked motivation and productivity. This was achieved by focusing on continuous teacher professional development strategies with the aim of creating a future labour-force that had the skills to meet the market demands of the 21 st century.

\subsubsection{The World Trade Organisation}

Furthermore, the dynamics that were influencing education policy and the development of Tatweer in Saudi Arabia were the result of the Kingdom's accession to the World Trade Organisation (WTO) in 2005. Niblock (2006:164) contends, that for oil rich Saudi Arabia, the need to distance itself "from ostracism in, and isolation from the Western world" in the aftermath of 9/11, was essential-a need that would be met, in part, through WTO membership. Saudi Arabia's accession to the World Trade Organisation (WTO) was symbolic in the sense that it would represent a fundamental step forward in working to create greater economic progress accrued from globalisation and WTO support. For Saudi Arabia, WTO membership represented both the county's integration into the accepted framework of international cooperation and as a means of addressing material policy change. In practice, supporting Niblock's (2006) claim would become more overt in the Saudi education Tatweer reforms.

In 2006, the Saudi government's Cultural Mission argued for the creation and education of a workforce that would meet global trends in economic development (Tatweer, 2008). The discourse of this reference clearly identifies the state's favour towards neoliberalism, which was the prevalent theme used by the state to highlight the need for reform. The narrative of crisis in education illustrated the urgency for reform, with the World Bank (2008) highlighting guiding principles for education development. It addressed the need for Saudi Arabia to prepare its population for the labour market within an innovative modern education system that catered for a global knowledge economy. Reform was, in-part, developed on the demands of the World Bank's participatory approach to membership in a world culture that would increase the efficiency and competitiveness of a global knowledge-based economy through a program of increasing literacy and numeracy by supporting teacher development (Dale, 1999).

2.1.3 Trends in International Mathematics and Science Study \& Programme of International Student Assessment

Nevertheless, the participation in the Trends in International Mathematics and Science Study (TIMSS) data scores and the Programme of International Student Assessment (PISA) as a measure to benchmark levels of education excellence, is another factor driving Tatweer. I will now illustrate that these drivers combined, worked as a catalyst to the expansion of teacher development initiatives and the creation of Tatweer Smart Schools (TSSs), a creation which would consequently witness substantial investment in ICTs in those schools too (Tatweer, 2014b). Subsequently, I can put forward several de-facto arguments that provide us with a rationale as to why Tatweer is significant across economic, political and social boundaries. First, good or 'smart' schools create and develop human capital by creating a measurable value. Secondly, the more human capital value that individuals acquire (from their school/ICTs), the more competitive the nation is. Finally, creating quality in an education system or measuring how effective or 'smart' a school is in creating such value can be measured with international standardised test scores (Smith and Baker, 2001; Wiseman and Baker, 2005). For Kamens and McNeely (2010) and Wiseman (2010), these arguments facilitate the use of global international comparative assessments as a legitimate measure to educational achievement. Two such international tests that typically dominate the debate on comparative education analysis is the Programme for International Student Assessment (PISA), and the Trends in International Mathematics and Science Study (TIMSS). These tests are formed from the agencies of power governance and arguably have created the potential to influence education policy through self-governance and mutual surveillance. Conceptualising the idea of Sahlberg's (2007:150-152) global reform movement, with a focus on standarisation, literacy and consequential accountability, made me realise that these principles were also steering Tatweer. As Saudi Arabia participates in the TIMSS and has a wider impact on the Saudi education context, the TIMSS and other drivers steering Tatweer will be now critically discussed.

\subsection{TIMSS-A Knowledge Policy Instrument in Tatweer Reform}

Post 9/11, the Saudi Ministry of Education sought to recognise "the critical role of human capital in transforming the quality of education services" by establishing reference points to "countries with higher performing education systems measured by the TIMSS or PISA results" (Tatweer, 2014b, p. 5). Here, Wiseman (2010, p. 34) highlights two main factors that define Saudi education development and which embody globalisation through a "contribution in a global education community, which are the participation in the TIMSS and the relatively recent Tatweer". The TIMSS generate quantitative data based on international comparative assessments in order to assist policy makers improve their respective educational systems and to evaluate educational reform (Martin, Mullis and Foy, 2008). Interestingly, Saudi Arabia's participation in the TIMSS is neither an example of coercive 
nor imposed action primarily because there are no "overt actors pushing for KSA [Saudi Arabian] participation particularly" (Wiseman, 2010, p. 34). For Tatweer, participation in TIMSS allows for the effective education comparisons of nations which can then create improvements in local education policy. This is reinforced by the Saudi Cultural Mission (2006) who state that international data comparisons assist reforming national policy by developing educational curricula to keep pace with economic and social developments and to benefit from the experiences of other nations. Thus, TIMSS highlight the state of global education. This is reflected not only in the 63 countries that participate in the current TIMSS, but also because it introduces 'reassurances' in a system which is seen to highlight standards of excellence in education within an expert-based impartial assessment framework (Tatweer, 2010, Tatweer, 2014b). I can therefore argue that the discourse around the importance of knowledge and data production to create a global knowledge economy have "gained increasing legitimacy in the KSA through their participation in TIMSS" (Wiseman, 2010, pp. 34-35).

In 2003, the OECD Secretary General, Mr. Angel Gurría stated "in a global economy, competitiveness and future education will depend on what people can do with what they know now" (Aljazeera, 2013:1). Critically, for Saudi Arabia, participation in transnational tests is an issue of status and a tool to legitimise reform. For Saudi education policy, the oil kingdom traditionally used international test results from other MENA states to influence its national policy structures (Wiseman et al., 2013). Interestingly, current TIMSS participation and planned 2018 PISA participation allows Saudi Arabia to be a partner in the world of globally competing nations. It gives it a separate identity from other Gulf and MENA states-allowing decentralisation from its other powerful oil rich OPEC (Organization of the Petroleum Exporting Countries) neighbours-at a time when Saudi Arabia attempts to restructure, reposition and resituate itself in a knowledge-based world.

The use of TIMSS and PISA benchmarking by Saudi Arabia to direct its education policy reform has therefore come to symbolise Tatweer through a performative action to create a "reform of indirect steering or steering from a distance which replaces intervention and prescription with target setting, accountability and comparison" (Ball, 1998:123). Berényi and Newman (2009, p. 43) note that it is in this respect that one should consider transnational testing can "create realities". For Saudi Arabia, it can be claimed that TIMSS becomes an effective performative instrument. It can be argued that TIMSS becomes a powerful example of global expansion that illustrates the debate legitimising education reforms. Being an actor of systematic governance on education, TIMSS and PISA permeate education, education discourse and education policy reform - by performing on a stage that enables us to witness the "global script" of how education policy is performed in national contexts (Ozga, 2012, p. 166). For Saudi Arabian education policy to be a producer of knowledge that addresses the needs of the knowledge economy, realising power structures and instruments of power are equally significant. Acknowledging TIMSS, World Bank or UNESCO influence as policy legitimisers and their role in forming of policies and public action are unavoidable (Lascoumes \& Le Galès, 2007).

In a UNESCO (2008, p. 6) National Report, Tatweer was hailed as a reform that "represents a landmark and one of the most essential projects of education development in the history of the Kingdom of Saudi Arabia". As Tatweer was created to improve the quality of teaching and learning in state schools, through (i) the implementation of new teacher professional development initiatives; (ii) new learning technologies in classrooms; and (iii) the development of greater teacher autonomy in state schools, I will now critically assess these points further. In turn, I would be able to raise some questions regarding reform implications and whether the Tatweer reforms were rigorous and effective enough in improving the level of education within the Saudi context.

\subsection{The Tatweer Reforms in Focus: Teacher Development and ICT}

Elyas and Picard (2013, p. 6) argue that Tatweer aims to "focus on the quality of education to ensure that students of public education in the Saudi Kingdom are equipped with the necessary skills to participate in an increasingly globalised society". In achieving this, Tatweer's (2014b, pp. 16-17) vision was a new school model that places students and schools at the heart of the education system "by enhancing teacher professional development as an embedded activity of the school...organized into professional learning communities... allowing them to learn from each other on an ongoing basis". Yet, to fully achieve this, Al-Degether (2009) calls for the support of teachers to facilitate quality Saudi education. By providing professional development workshops to improve teacher skills and instruction, an improved system of education would result. Consequently, in aiming to develop teacher skills, a greater move to involve entrepreneurial enterprises became apparent. Therefore, to address labour market needs, a cooperative partnership with the National Center for Teaching and Thinking (NCTT) was introduced in 2007 to assist in teacher professional development and to raise standards in student numeracy and literacy (Tatweer, 2010). Yet, recognition of the marketisation of Saudi education policy itself was highlighted with the 2008 transformation of Tatweer into a holding company owned 
by a multi-billion dollar Saudi Public Investment Fund (SPIF). The SPIF was to provide financial support to productive projects of a commercial nature in order to assist in the development of the national economy (SWFI, 2015; Tatweer, 2010). The move was intended to create partnerships with international organisations to develop an education industry that would witness excellence in teacher development and support initiatives, improved student literacy levels and a modernised curriculum manifested through technology use in 'smart schools', i.e, the Tatweer Smart Schools (TSSs). Steiner-Khamsi (2004, p. 2) assert that this then created a model of scientific rationality that allowed "political stakeholders in education to appeal to the general public" when planning for comprehensive education reform.

For Sahlberg (2010), schools play an important role in creating a knowledge-based economy, as evidenced in Finland; however, this would not have been possible if the skills and professional development of Finnish teachers were not realised (Sahlberg, 2010:3). With Tatweer, we are led to believe its objectives are for the benefits of teaching professionals, students and the economy. Yet, much of the reforms witnessed internal conflicts and a mismatch of resources in initiatives focused on the training of teachers (Wiseman et al., 2013). Thus, it can be argued that a neoliberal paradox emerged. This is perhaps an example of the irrationality and power struggles that are, at times, prevalent in education reform. In practice, the teacher and education reform goals set forth in Tatweer highlights the de-attachment of key drivers in the plan itself. The mismatch between resources and training, on the one hand, and the goals of Tatweer, on the other, created a vacuum of disparity. Al-Essa (2009) suggests several reasons for this. But one that stands out to me as an educator in Saudi Arabia, is the failure to implement education reform which effectively addresses and supports teacher autonomy.

\subsection{Teacher Autonomy}

Hargreaves and Shirley (2009) argue that the quality of teachers and the autonomy they deserve are essential to successful education reform. Sahlberg (2007) asserts that the success of the Finnish education system can be attributed to the dynamics of quality evident in teachers and teaching. This is seen in contrast to Alnahdi (2014, $p$. 3) arguments that, in the case of Saudi Arabia, "teachers no longer have the social status of previous time periods when they had special respect and status." Therefore, two questions arise here. Firstly, if Tatweer is seen by the Saudi Ministry of Education as an approach driven and supported by economic goals, does this not undermine the principle of 'ethical' education? Secondly, how would it be possible for teachers to be autonomous if they are guided by economic principles? With Tatweer, I believe an 'illusion' of teacher autonomy is presented, not only because Tatweer was implemented with market objectives and without the effective training of teachers to meet these objectives, but, significantly, because its centralised system of power was characterised by the weak authority given to teachers in the Saudi education system itself (Alyami, 2014; Wiseman et al., 2013).

With the state intent on meeting economic goals, without understanding the foundations on which education rests upon, Tatweer consequently faced many challenges throughout the implementation stages of reform before establishing consensus and "organisational and community legitimacy or capacity development" (Wiseman et al., 2013, p. 41). Tatweer's overzealous benchmarking of a European education superpower (Finland), without realising the unique environment and culture in which it operates in, created the circumstances, irrationality and disconnection that became apparent in Tatweer. As a result, the neoliberal values of autonomy, trust, and greater leadership powers for teachers evident in Tatweer discourse were overshadowed by the performance devices of human capital and the dynamics of disciplinarily power control, and authority. This is made apparent through Foucault's (1977) panopticon model of modern disciplinarily power - an argument sustained by Downing (2008), where coercion is exercised and maintained through observation.

In contrast, Finnish education reforms and teacher autonomy were built on creativity, the long hours teachers were working, and the liberal culture of its society (Sahlberg, 2007). Reforms were slow, but set in Finnish culture, Finnish values, and based on a long-established reform changes. In contrast, Tatweer was set in unchartered terrain and was implemented using international models linked to global trends aimed at primarily generating human capital benefits for the economy. This is evidenced with the introduction of Tatweer Smart Schools. This not only facilitated Tatweer's emphasis on human capital, but created the scene for neoliberal principles to evolve further with the implementation of technology as catalyst to such principles (Wiseman et al., 2013).

\subsection{TSS: ICT as A Support Structure to Educational Development and Performance}

Discourse in Tatweer (2014b:18) literature highlights that although a seemingly small amount of ICT programs to facilitate learning and teaching were used in the Saudi classrooms before Tatweer implementation, they were nevertheless limited in scope. They did not assist failing students in improving cognitive development or facilitate practical skills application in the class, nor did they provide extra-curricular programs to enrich 
learning. A UNESCO (2007) published research report emphasised the significance of promoting greater ICT utilisation as part of any future Saudi state reform package. The report promoted the benefits of ICT in creating "new vistas for learning" (Bashur, Albassam, \& Benjelloun, 2007, p. 11). Framed by neoliberal thought, Tatweer worked to institutionalise ICT resources in the classroom, creating a revolutionary new approach to teaching and learning in Tatweer Smart Schools (TSSs) to meet the needs of a global knowledge economy.

Implementing TSSs began with the establishment of 50 pilot smart schools (24 boys' secondary schools and 25 girls' secondary schools) throughout the 25 provinces in Saudi Arabia (Alyami, 2014). These schools were considered by many policy makers as an innovative approach to a new education system that realised the significance of globalisation and importance of technologies in producing a workforce that met the needs of the global market (Wiseman et al., 2013). Consequently, a technology-orientated reform was implemented in all pilot schools, that included wireless internet access, smart-board use, LCD projectors and digital cameras installed in all classrooms for instruction purposes and laptops distributed to every teacher and student (Alyami, 2014; Tatweer, 2008). This was considered as an innovative approach to "provide a new venue for the students to grow and flourish in areas such as entrepreneurship, ICT , reading and writing" and to push the Saudi education system into a new era that would create learners fit for 21st labour market needs (Tatweer, 2014b, p. 18).

Critically important to note, TSS were seemingly introduced through a state-controlled national consensus. Students, school teachers and management, even national committees, were not consulted or established to discuss the implications and limitations of ICT integration into the pilot schools. Thus, Tatweer portrayed the power of the state to exert reform and implement power as a capacity - exerting power on the relations between teachers and students - with the state working as a configuration of multiple power relations throughout different social levels. Through surveillance, disciplinarily power is exercised and conservative social values are maintained (Foucault, 1991). From a perceived form of teacher autonomy to the creation of a class system that worked in "substitute principles of power for a government" (van Zanten, 2005, p. 257), it can be safely claimed that TSS were introduced as a power tool in creating a coherent framework of political and economic agendas to the education level - a fabrication of a knowledge community under legitimised state power (Foucault, 1991). Here, Wiseman (2013, p. 40) argues that at the time TSS were implemented, the global discourse of human capital prevalent in Saudi Arabia was a key driver that became the "legitimised rationale for the technical use of ICTs in Saudi schools"- an outcome of power dominance and influence through governance.

Nevertheless, Tatweer (2014a) reforms attempted at devolving greater accountability to each school, arguing that "managing student performance is a core leadership function at the school level, data about student performance is captured, stored, and analyzed on a continuous basis" (Tatweer, 2104b, p. 17). However, this saw teachers becoming measurable variables related to the educational performance of their students, while being held to account on their own performance and the performance of their school. This then results in a performative technique described by Ball (2003), which embodies the changing relationships between power, knowledge, government and education. He (2003, p. 16) defines performativity as "a technology, a culture and a mode of regulation that employs judgments, comparisons and displays as a means of incentive, attrition and change based on rewards and sanctions". Though ICT use in TSS incorporated pedagogical drivers to improve teacher and student learning through technology-based instruction, Wiseman et al., (2013) argue that its practical applications were sparse and late. Consequently, a paradox emerged. By making schools more visible and improving ICT-mediated instruction to the manipulation of output and performance, witnessed an irony in the reform itself. A contradiction emerged in ICT implementation in relation to the costs, times and resource allocations of activities. It witnessed an economic-based education reform transform "commitment, judgment and authenticity... sacrificed for impression and performance" (Ball, 2003, p. 221). Interestingly, important questions to raise here is that while Tatweer/TSS were formed and legitimised by the human capital benefits of ICT implementation to create a self-sustaining knowledge workforce, how could the experiences of the past help develop improved reform and what would the reaction of teachers and students be in response to desires in human capacity building? What would be the impact, the possible obstacles, and measures adopted to implement future educational development programmes be? Nonetheless, for Saudi education policy, Tatweer portrays teachers and the development of educational practice as a tool of and for the state, motivated by global market forces under a transnational neoliberal governmentality that imposes power on individuals (Foucault, 1991). The responsibilities of the teacher to their students, the concepts of trust, the significance ICT implementation as a support structure to learning/teaching, and the significance of teacher autonomy in Tatweer are somewhat displaced by neoliberal tenets, both through the direct power technologies the state and through the discourses of competitiveness, performance and increasing efficiency prevalent throughout policy literature. 


\section{Future Implications}

By noting several thought-provoking questions, the critical rhetoric surrounding the challenge of supranational institutions (including the IEA, OECD and UNESCO) and its promotion of comparative/competitive narratives are therefore worthwhile to address. Questions rest with concerns regarding value, interests and application. For example, (i) where do IEA/UNESCO/World Bank/OECD vested interests lie; (ii) what specific benefits do these institutions offer to underperforming education systems; (iii) how can neoliberal principles be effectively applied to other (developing and religiously conservative) nation states; and (iv) if Western neoliberal thought is applied to member states, would this constitute the suppression or erosion of traditional values and cultures of the nation in favour of becoming a mosaic of a larger picture of global Western dominance? However, what is more significant to identify is how countries with low scores on the TIMSS, prevalent in most MENA/Gulf states, can successfully implement a policy change based on supra-national statistics at the local level. As the Tatweer education reforms were introduced to improve numeracy and literacy in order to develop a knowledge-based economy to meet labour market needs, I think remnants of local policies, culture, values and norms would still need to preside in some form within any educational transition. The impact of globalisation and the mechanisms driving neoliberal policy should perhaps be placed within a 'glocalised' context-globalisation tailored to the local level. By this, national policy makers should realise any reform change made to address the effects of globalisation should address the local context, values, cultures, customs and history of the nation. This would perhaps create a more effective transition to reform by tailoring local needs to international requirements. However, a wider understanding of what and how performing countries have identified and implemented policy in their local context is equally important.

By analysing the success of the Finnish education system, Sahlberg (2013) highlights two key drivers which positively affect the success and quality of education policy development. First, strengthening educational equity, where schools focus on the student rather than on academic achievement can be achieved through the provision of equal and positive learning opportunities. Secondly, supporting teacher autonomy by promoting work in a collaborative work culture that allows teachers to share ideas, engage in best practice and build up professional networks for future development opportunities are equally significant. Though, attempts to address effective continual professional development initiatives for school teachers have been adopted by the Tatweer policy, I believe this has been manifested through the illusion of autonomy. For Al-Essa (2009), even though Tatweer's policy goals and objectives are significant representations of the direction of reform, three years after the 2008 implementation of Tatweer, little has yet to be witnessed in terms of a relative improvement in the Saudi education system.

\section{Conclusion}

The Saudi Tatweer education reforms have been important in highlighting questions about power, globalisation and divergence. The fabric of power lies with the state of Saudi Arabia which has demonstrated its neo-institutional frameworks in response to the growth of globalisation and influence of supranational institutions. To balance the impact globalisation has created on education demands, what Saudi education reform requires is equilibrium in its education policy and approach to implementation. Arguably, establishing reforms which go beyond power-orientated relationships are significant for any successful education reform in Saudi Arabia. Implementing education policy within a context unique to its own national education setting, values, history, environment and culture may indeed witness the spawning of a Saudi education system that can be, in many respects, comparable to many of the world's education superpowers.

\section{References}

Al-Degether, R. (2009). Teacher educators'opinion and knowledge about critical thinking and the methods they use to encourage critical thinking skills in five female teacher colleges in Saudi Arabia (Unpublished $\mathrm{PhD}$ thesis). Retrieved from ProQuest Dissertations and Theses PQDT. (3352791).

Al-Essa, A. (2009). Education Reform in Saudi Arabia between Absence of Political Vision, Apprehension of the Religious Culture and Disability of Educational Management. Beirut: Dar AlSakee Publishers.

Aljazeera. (2013, December 4). Global education survey puts Shanghai on top. Retrieved June 15 2016, from http://www.aljazeera.com/news/asia-pacific/2013/12/global-education-survey-puts-shanghai-top-20131242 2458196183.html

Alnahdi, G. (2014). Educational change in Saudi Arabia. Journal of International Education Research, 10(1), 1-6. Retrieved April 3 2015, from http://www.researchgate.net/publication/270386601_Educational_Change _In_Saudi_Arabia 
Alyami, R. (2014). Educational reform in the Kingdom of Saudi Arabia: Tatweer schools as a unit of development. Literacy Information and Computer Education Journal, 5, 1424-1433. http://doi.org/10.1007/s10639-016-9477-x

Aubert, J. E., \& Reiffers, J. L. (Eds.) (2003). Knowledge Economies in the Middle East and North Africa. Toward New Development Strategies. Washington D.C: The World Bank.

Ball, S. (1998). Big policies/small world: An introduction to international perspectives in education policy. Comparative Education, 34(2), 119-130. http://doi.org/10.1080/03050069828225

Ball, S. (2003). The teacher's soul and the terrors of performativity. Journal of Education Policy, 18(2), 215-228. http://doi.org/10.1080/0268093022000043065

Ball, S. (2008). The education debate. Bristol: Policy Press.

Bashur, M., Albassam, D. \& Benjelloun, W. (2007). The Impact of Globalization on Higher Education and Research in the Arab States. In UNESCO (Ed.), Proceedings of the UNESCO Forum on Higher Education, Research and Knowledge (pp. 11-87). Paris: UNESCO.

Berényi, E., \& Newman, E. (2009). Grapling with PISA. Reception and translation in the Hungarian policy discourse. Educational Sciences Research Journal, 10, 41-52.

Chinnammai, S. (2005, November). Effects of globalization on education and culture. Paper presented at the ICDE International Conference, New Delhi.

Dale, R. (1999). Specifying globalisation effects on national policy: a focus on the mechanisms. Journal of Education Policy, 14, 1-17. http://doi.org/10.1080/026809399286468

Dicken, P. (2011). Global shift: Mapping the changing contours of the world economy. London: Guilford Press.

Downing, L. (2008). The Cambridge Introduction to Michel Foucault. Cambridge: Cambridge University Press. https://doi.org/10.1017/CBO9780511793240

Elyas, T. (2008). The attitude and the impact of American English as a global language within the Saudi education system. Novitas Royal, 2(1), 28-48.

Elyas, T., \& Picard, M. (2010). Saudi Arabian educational history: Impacts on English language teaching. Education, Business and Society: Contemporary Middle Eastern Issues, 3(1), 136-145. http://doi.org/10.1108/17537981011047961

Elyas, T., \& Picard, M. (2013). Critiquing of higher education policy in Saudi Arabia: Towards a new neoliberalism. Education, Business and Society: Contemporary Middle Eastern Issues, 6(1), 31-41. http://doi.org/10.1108/17537981311314709

Foucault, M. (1977). Discipline and Punishment: The Birth of the Prison. Penguin, London.

Foucault, M. (1991). Governmentality. In G. Burchell, C. Gordon, \& P. Miller (Eds.), The Foucault Effect: studies in governmentality. Chicago: Chicago University Press.

Grek, S., Lawn, M., \& Ozga, J. (2009). PISA and the policy debate in Scotland: Policy narratives about Scottish participation in the international comparison. Educational Sciences Journal, 10, 73-84.

Gronmo, L., \& Onstad. T. (Eds.) (2013). The significance of TIMSS and TIMSS Advanced. Oslo: Akademika Publishing.

Hargreaves, A. (2003). Teaching in the knowledge society: Education in the age of insecurity. New York: NYTC Press.

Hargreaves, A., \& Shirley, D. (2009). The fourth way: The inspiring future for educational change. Boston: Boston College School of Education.

Harvey, D. (2005). A brief history of neoliberalism. Oxford, OUP.

International Monetary Fund. (2013). Saudi Arabia Article IV Consultation. Retrieved June 15 2016, from https://www.imf.org/external/pubs/ft/scr/2013/cr13229.pdf

Kamens, D., \& McNeely, C. (2010). Globalization and the growth of international educational testing and national assessment. Comparative Education Review, 54(1), 5-25. https://doi.org/10.1086/648471

Lascoumes, P., \& Le Galès, P. (2007). Understanding public policy through its instruments-from the nature of instruments to the sociology of public policy instrumentation. Governance: An International Journal of Policy, Administration and Institutions, 20(1), 1-21. https://doi.org/10.1111/j.1468-0491.2007.00342.x 
Maroun, N., Samman, H., \& Abouchakra, R. (2008). How to succeed at educational reform. The case for Saudi Arabia and the Broder GCC Region. United Arab Emirates: Booz Allen Hamilton.

Masri, M. (2009). Policy process and education reform in the Arab world. Mediterranean Journal of Education Studies. 14(1), 129-144.

Niblock, T. (2006). Saudi Arabia: Power, legitimacy and survival. London: Routledge.

OECD. (2008). Education at a glance. Education indicators. Paris: OECD. https://doi.org/10.1787/eag-2008-en

Ozga, J. (2012). Assessing PISA. European Educational Research Journal, 11(2), 166-171. http://doi.org/10.2304/eerj.2012.11.2.166

Prokop, M. (2003). The politics of education. International Affairs, 79(1), 77-89. https://doi.org/10.1111/1468-2346.00296

Robertson, M., \& Alzahrani, A. (2012). Self-efficacy and ICT integration into initial teacher education in Saudi Arabia: Matching policy with practice. Australasian Journal of Educational Technology, 28(7), 1136-1151. https://doi.org/10.14742/ajet.793

Sahlberg, P. (2007). Education policies for raising student learning: the Finnish approach. Journal of Education Policy, 22(2), 147-171. http://doi.org/10.1080/02680930601158919

Sahlberg, P. (2010). The secret to Finalnd's success: Educating teachers. Stanford Center for Opportunity Policy in Education: Stanford: Stanford University School of Education.

Saudi Arabian Cultural Mission. (2006). Educational system in Saudi Arabia. Washington D.C: Saudi Cultural Mission. Retrieved June 15, 2016, from http://www.sacm.org/Publications/58285_Edu_complete.pdf

Smith, T., \& Baker, D. (2001). Worldwide growth and institutionalization of statistical indicators for education $\begin{array}{lllll}\text { policy-making. Peabody Journal of } & \text { Education, }\end{array}$ https://doi.org/10.1207/S15327930PJE763\&4_9

Steiner-Khamsi, G. (2004). The politics of league tables. Journal of Social Science Education, 1. Retrieved June 15 2016, from http://www.tc.columbia.edu/faculty/steiner-khamsi/_publications/Gitas\%20Professional\%20 Files/Publications\%20peer\%20review/PoliticsLeagueTables2003.pdf

SUSRIS. (2015). King Abdullah Bin Abdulaziz Public Education Development Project. Retrieved June 112016 , from http://susris.com/glossary/king-abdullah-bin-abdulaziz-public-education-development-project/

SWFI. (2015). Public Investment Fund. Retrieved June 11 2016, from www.swfinstitute.org/sefs/public-investment-fund/

Tatweer. (2008). A Comparative Analysis of National Education Development and eLearning in Various Countries. Riyadh: King Abdullah Bin Abdulaziz Project for Public Educational Development.

Tatweer. (2014a). T4EDU Math and Science Teacher Development Programme expected to have positive impact on math and science education in Saudi Arabia. Retrieved June 15 2016, from http://www.pearsonmiddleeastawe.com/t4edu-math-and-science-teacher-development-programme-expected -to-have-positive-impact-on-math-and-science-education-in-saudi-arabia

Tatweer. (2014b). Preliminary Scope of Work: Project to Manage the Teacher Professional Learning Abroad Program. Riyadh: Tatweer for Educational Services.

UNDF. (2003). Regional Report: Arab States. Retrieved June 10 2016, from http://hdr.undp.org/en/reports/regionalreports/arabstates/RBAS_ahdr2003_EN.pdf

UNESCO National Report. (2008). National Report on Saudi Arabia 2008. Retrieved June 10 2016, from www.ibe.unesco.org/National_Reports/ICE_2008/saudiarabia_NR08_en.pdf

Van Zanten A. (2005). Bourdieu as education policy analyst and expert: a rich but ambiguous legacy. Journal of Education Policy, 20(6), 671-686. http://doi.org/10.1080\%2F02680930500238887

Wiseman, A. (2010). The institutionalization of a global education community: The impact of imposition, invitation and innovation in the Gulf Cooperation Council (GCC). Orbis Scholae, 4(2), 21-4.

Wiseman, A., \& Anderson, E. (2012). ICT-integrated education and national innovation systems in the Gulf Cooperation Council (GCC) countries. Computers and Education, 59, 607-618. http://doi.org/10.1016/j.compedu.2012.02.006

Wiseman, A., \& Baker, D. (2005). The worldwide explosion of internationalized education policy. In D. Baker, 
\& A. Wiseman (Eds.), Global Trends in Educational Policy (pp. 1-21). London: Elsevier. https://doi.org/10.1016/S1479-3679(04)06001-3

Wiseman, A., Astiz, M., \& Baker, D. (2013). Globalization and comparative education research: Misconceptions and applications of neo-institutional theory. Journal of Supranational Policies of Education, 1, 31-52.

Wiseman, A., Sadaawi, A., \& Alromi, N. (2008). Educational Indicators and National Developments in Saudi Arabia. Paper presented at the $3^{\text {rd }}$ IEA International Research Conference, Taipei.

World Bank. (2008). The Road Not Travelled. Education reform in the Middle East and Africa. Washington D.C: The World Bank.

\section{Copyrights}

Copyright for this article is retained by the author(s), with first publication rights granted to the journal.

This is an open-access article distributed under the terms and conditions of the Creative Commons Attribution license (http://creativecommons.org/licenses/by/4.0/). 